\title{
THE CONTEMPORARY COUNTRIES IN THE CONDITIONS OF MIGRATORY MULTICULTURALISM
}

\author{
Manol STANIN \\ "Neofit Rilski" South-West University- Blagoevgrad, Bulgaria \\ stanin@abv.bg
}

\begin{abstract}
One of the characteristics in the early 21st century is the existence of different in intensities and content migration waves. This confronts the countries at a range of challenges.

On one side, countries should protect the rights, freedoms and interests of its citizens, on the other rights, freedoms and interests of persons, who form migratory pressure and are threatening the national security. In order to be guaranteed the rights, freedoms and interests, it is necessary first to be ensured a security, which means limiting the rights of persons, who represent a threat to the national security. The problems are further exacerbated by the enforced coexistence of different cultures with values different from those of the citizens in the respective countries, which are reflected in the current legal order. This, in turn, means a normative impossibility for the institutionalization of these values and the adoption of legislative consensual solutions, applicable as for the time of their stay in the respective countries, as well as in their eventual integration.
\end{abstract}

Keywords: multiculturalism, values, rights, conflict, integration

\section{Introduction}

The beginning of XXI century is characterized by the emergence and exacerbation of conflict zones around the world and with the consequences of the global financial crisis - factors that generate varying in degrees of intensity and content migration waves. These are factors, which challenge the countries with the choice to protect the rights, freedoms and interests of persons, involved in the formation of migratory pressure or to protect the rights, freedoms and interests of its citizens. Complete guarantee of the rights and freedoms is possible only in a state of security. This, in turn, means limiting the rights and freedoms of persons, who are a threat to the national security - a task, to fulfilment of which the contemporary states should proceed.
Thereby would be sustained the effective interaction between governed (nation) and government, manifested in different fields, including in the achievement of a homoeostasis in the community.

\section{Values and legal regulation}

The idea of nationalism usually is gaining popularity during periods of presence of large numbers of foreigners, whose value system is contradictory with the values, manifested in the relationship between nationals of the respective country. Thus, cause a series of problems, additionally exacerbated by the incompatibility of values. The latter finds an expression in the diversity, concerning the understanding of good - evil, fair - unfair, sin, status of genders in society and others, which are arising from specifics of the different cultures that honour different values. With 
the feature that the existing legal order in the host country reflects and protects values, unacceptable and even incomprehensible for some of the immigrants - a fact, which determines the lack of a community of values between nationals and immigrants. It naturally excludes or makes difficult not only the integration of the immigrants, but also generates a number of problems during their residence in the territory of the relevant country. This ascertainment means normative impossibility of consensual legislative solutions, applicable for the period of their stay in the respective countries, as well as for their eventual integration.

In the context of what has been said so far, it seems to me appropriate to remind that there are hundreds of definitions for culture. With a view to the present analysis, a 'culture' means a complex of values, reflected in the social regulatory systems, designed to influence the behaviour of individuals, who exist in the conditions of community. Of special importance is the normative system "law" as "the individuals (legal entities) through their rights are integrated into a community (nation) in the name of certain values and interests enshrined in the Law." [1] And the rights, regulated by the law, imply obligations for assistance in their exercising or obligations not to hinder their titular, when he exercises them. Fulfilment of these obligations positively influences the homeostasis within the community of individuals. Thus, through positive mutual respect for the rights sanctioned by the law, individuals deepen the integration processes in the community.

It is logical to presume the contrary. Negligence of obligations leads to disintegration, even for individuals, who a part of the community, because this is not only a legal infringement, but also a disrespect for the values of that society. These dependencies could be applied in relation to persons, who are positioned in one country, because of migratory or refugee waves. In that sense each conflict situation, resulting from the abovementioned processes, is both a conflict of values and a conflict over rights. Defining the possible and the appropriate behaviour of the individuals poses a number of urgent tasks before the subject of the legislative activity. From properly taken legislative decisions depends the mutual respect for rights, values and naturally, the right to pursuit a building community. [2] These ascertainment suggest the powerful integration potential of law. [3] Potential, which the contemporary countries should use wisely, as it may also lead to serious negative consequences.

\section{Multiculturalism and administration of justice}

The accompanying migration multiculturalism reflects both positively and negatively to the integration processes, as it is also a prerequisite for increasing the transnational criminality. The violation of the established legal order, created because of the dominant in the country value system, is often a ground for defining and implementing a measure of criminal law responsibility. The question of whether the criminal proceedings against the offender should be initiated and conducted in the country of stay of the person - immigrant, refugee, temporary resident - could be solved through the mechanisms of criminal law cooperation between countries. Thus, the offender could be tried and penalized either in country of his residence or in his native country. There is another possibility - after he is sentenced in the country of his residence, to be transferred for serving the sentence in his native country, where the conditions for social reintegration, respectively for correction and re-education are more favourable. [4] Thereby is revealed the mutual interrelatedness between values, culture, equity and justice globally. 


\section{Legal regulation and security}

It is accepted that 1960 is the year of occurrence of the concept of multiculturalism, which with time takes precedence over the so-called "assimilation model" in dealings with immigrants. The realization of the idea of co-existence of different in their essence cultures, on the territory of one country, gradually forms difficult and even impossible to solve problems in front of the contemporary countries.[5] From the available diversity I will put an emphasis on two problematic areas - legislative activity and guaranteeing security, with a view of their importance to the maintenance of unity and consensus not only of the community of nationals of one country, but also unity and consensus of the community of nations.

Related to the co-existence of several nations within the European union, in the theory has been said that: "The presence of a number of multifaceted challenges and asymmetric threats, despite its negative impact on the functioning of the European Union itself lead to a deterioration in the level of security and stability in the EU's neighbouring regions. In this regard there should be paid special attention to a new phenomenon in the contemporary reality, namely mass migration to the old continent of unstable political and economic regions of the so called Third World, adjacent to Europe." [6]

\section{The law and the rights seen as integration instruments}

Naturally, it should be recognized the right of everyone to migrate or seek refugee status. Like any right, however, there are limits for its exercising. This right could be restricted by establishing obligations or prohibitions as well as through factual activities, mostly from the countries, to which the persons concerned are directed, including the countries, through the territory of which they are only passing. In the context of what has been said, it should be kept in mind that after exercising of a right there are consequences, with which the one, who has exercised it, must comply. These consequences suggest an interaction with a community of nationals with their cultural identity. Such interaction could be regulated only by the existing legal order in the country, which usually contains and protects values incompatible with the value system of the majority of these individuals. Values are the foundation of the boundaries characterizing each community of people. The borders stem from the necessity and the causes for building of community and connect with the territory and its resources, and with a sense of connectivity and reciprocity. [7] For these reasons, according to the cited author, it is fully justified if the inclusive community that has a country put its integrity and identity in the first place. Therefore, the source for problematic situations, as well as sustainability, is the interaction that raises the question of the development of conflictology of cultures or intercultural mediation, including issues related to the legal regulation of these processes.

It is also possible a process of rejection and unwillingness for interaction. Migrants crossing the border of a country find existing community with expressed values and territorial boundaries, which are shared a prolonged period, sufficient to form a nation. Moreover, if the passage of the first boundaries proves relatively easy, often the second boundary is difficult and even insurmountable, since its components have values that foreigners do not understand, do not accept and even reject. In the presence of a critical mass of foreigners with common values that determine their behaviour, it is quite natural for them to start building a community, when the above stated circumstances are present. The consequence is creating an environment for the expression of cultural values that they have "ported". These processes involve conflicts at every social interaction between individuals from both communities. Actually, this is not a conflict situation, 
based on incoherencies in behaviour, resulting from the different cultures, between specific individuals. It is a conflict between the cultures, because it is expected and even predictable between individuals from culturally incompatible communities. What has been said so far does not exclude risks and challenges facing the countries in the absence of the above mentioned conflict situations, resulting from the cultural incompatibility. Even the presence of sustainable integration processes implies risks in the conduct of their legislative activity in the field of possible and appropriate behaviour of the representatives of different cultures.

In the light of the concept of multiculturalism, measures are taken to maintain the cultural identity of immigrants. Despite the fact that the concept of "culture" has many definitions, in 1952 have been ascertained 164 [8], it is easy to assume that in 2017 their number has increased significantly. The diversity, however, contains something constant. Culture connects with people. It is the product of a lengthy process with its specifics. [9] Each analysis of a particular culture is positioned on the extended time basis, covering both the present and the history of a nation. The nation is defined as the natural environment of the existence of legislative factors (justice, morality, economic condition, politics, biology, geography, demography, etc.) and therefore is of a great importance in their transformation into national positive law. [10]

\section{Conclusion}

Reporting of these features is particularly important for the legal entity of the legislative activity, elected from the nationals of each country to create law. Any thoughtless and randomly shifting the focus to maintain the cultural identity of immigrants may form disturbances in the legislative process with negative consequences for the legal certainty.

\section{References}

[1] Колев, Т. Правото и правата като културен феномен, Сиела, С., 2015, с. 21.

[2] У., Майкъл. Сфери на справедливостта, ИК КК, с. 90.

[3] Низбет, Р. Стремежът към общност. Център за изследване на демокрацията, International for Contemporary Studies International Center for Self Covernance, 1992.

[4] Voynova, R. Comparison of the Transfer of Criminal Proceeding with other forms of International Legal Cooperation in Criminal Matters, in scientific collection "The complex physiognomy of the International security environment", Land Forces Academy "Nicolae Balchesku", Sibiu, Romania, 2015, pp. 178-186.

[5] Mihaylov, G. Law in the Process of Social Integration of Immigrants, in scientific collection "Economic, Social and Administrative Approaches to the Knowledge-Based Organization", Volume II, Land Forces Academy "Nicolae Balchesku", Sibiu, Romania, 2016, p. 12.

[6] Marin, N. Disproportionate Migration Pressure as a Challenge for the National Security of the Republic of Bulgaria, in scientific collection "Economic, Social and Administrative Approaches to the Knowledge - Based Organization", Volume II, Land Forces Academy "Nicolae Balchesku", Sibiu, Romania, 2016, p.134.

[7] L. Friedman. Is there a modern legal culture? Ratio juris. Volume 7, Issue 2, July 1994 , pp.117-131.

[8] A. Kroeber, C., Clachohn, Culture. A critical review of concepts and definitions, Cambrige (mass), 1952 
[9] Vasilev, V., I.Efremovski, Organizational culture and motivation in public administration - a relation of the future in the public management, Journal of Process Management New Technologies, 2014: pp. 101-106.

[10] Колев, Т. Теория на правотворческата дейност, Университетско издателство „Св. Климент Охридски“, С., 2006, с. 188 